\title{
Kivilompolo Mo mineralization in the Peräpohja belt revisited: Trace element geochemistry and Re-Os dating of molybdenite
}

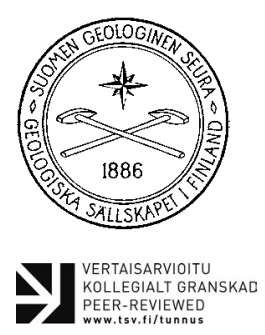

\author{
Jukka-Pekka Ranta ${ }^{\mathrm{I}^{*}}$, Eero Hanski ${ }^{\mathrm{I}}$, Holly Stein ${ }^{2,3}$, \\ Matthew Goode ${ }^{4}$, Timo Mäki ${ }^{5}$, Atte Taivalkoski ${ }^{1}$ \\ ${ }^{1}$ Oulu Mining School, University of Oulu, P.O.BOX 3000, FI-90014, Finland \\ ${ }^{2}$ AIRIE Program, Colorado State University, 1482 Campus Mail, Fort Collins, \\ CO 80523-1482, USA \\ ${ }^{3}$ Institute of Geosciences, University of Oslo, 1047 Blindern, 0316 Oslo, Norway \\ ${ }^{4} 84$ Ballinteer Park, Ballinteer, Dublin 16, D16 HK46, Ireland \\ ${ }^{5}$ Näsilinnankatu 7 D 48, 33210 Tampere, Finland
}

\begin{abstract}
The Kivilompolo molybdenite occurrence is located in the northern part of the Peräpohja belt, within the lithodemic Ylitornio nappe complex. It is hosted within a deformed porphyritic granite belonging to the pre-orogenic $1.99 \mathrm{Ga}$ Kierovaara suite. The mineralization occurs mostly as coarse-grained molybdenite flakes in boudinaged quartz veins, with minor chalcopyrite, pyrite, magnetite, and ilmenite. In this study, we report new geochemical data from the host-rock granite and Re-Os dating results of molybdenite from the mineralization. For the whole-rock geochemistry, the mineralized granite is similar to the Kierovaara suite granites analyzed in previous studies. Also, the ca. $2.0 \mathrm{Ga}$ Re-Os age for molybdenite is equal, within error, to the U-Pb zircon age of the Kierovaara suite granite. In addition, similar molybdenite and uraninite ages have been reported from the Rompas-Rajapalot Au-Co occurrence located $30 \mathrm{~km}$ NE of Kivilompolo. We propose that the magmatism at around $2.0 \mathrm{Ga}$ ago initiated the hydrothermal circulation that was responsible for the formation of the molybdenite mineralization at Kivilompolo and the primary uranium mineralization associated with the Rompas-Rajapalot Au-Co occurrence or at least, the magmas provided heating, and in addition potentially saline magmatic fluids and metals from a large, cooling magmatic-hydrothermal system.
\end{abstract}

Keywords: Molybdenum, Porphyry deposits, Peräpohja belt, Finland, Re-Os dating

*Corresponding author (e-mail: jukka-pekka.ranta@oulu.fi)

Editorial handling: Alexander Slabunov (e-mail: slabunov@krc.karelia.ru) 


\section{Introduction}

Most of the world's molybdenum comes from magmatic-hydrothermal porphyry type deposits, with Mo being either the main product (porphyry Mo$\mathrm{Cu}$ ) or a by-product from the copper production (porphyry $\mathrm{Cu}-\mathrm{Mo}$ ). In Finland, several small molybdenite occurrences are known, both in Archean and Paleoproterozoic terranes (Fig. 1). They are related to granites and resemble porphyry-style deposits. The Archean Mätäsvaara Mo deposit is the only one that has been exploited in the past, which took place in the 1940's (e.g., Haapala \& Rämö, 2015, and references therein).

The molybdenite in the Mätäsvaara deposit is hosted by quartz and pegmatite veins in Neoarchean tonalite gneiss and microcline granite (Haapala \& Rämö, 2015), and provided the first NTIMS Re-Os ages for molybdenite (Stein et al., 1995). Matasvaara's complicated magmaticmetamorphic history prompted the Re-Os dating of another Archean Mo occurrence at Aittojärvi (Markey et al., 1999) hosted in homogeneous felsic-silicic leucosomes in an altered gneissic granitoid at the northern end of the KuhmoSuomussalmi greenstone belt (Haapala \& Rämö, 2015). Building on the suspected and then proven spatial decoupling of parent-daughter $\left({ }^{187} \mathrm{Re}-{ }^{187} \mathrm{Os}\right)$ isotopes in the Aittojärvi molybdenites (Stein et al., 2001, 2003), further non-reproducible Re-Os age determinations of 2791 to 2809 Ma for Aittojärvi (Selby \& Creaser, 2004) led these authors to recommend a minimum of $40 \mathrm{~g}$ molybdenite for all Re-Os age determinations. Ultimately, sample size was shown not to be a factor in achieving accurate Re-Os ages for molybdenites (Stein, 2006; Stein et al. 1997). Other pioneering work on molybdenites from Finland led Stein et al. (1998) to the Kuittila Au prospect in the Hattu belt in eastern Finland (Nurmi \& Sorjonen-Ward, 1993). The Kuittila $\mathrm{Au}$ occurrence is hosted by a TTG-series (tonalitetrondhjemite-granodiorite) pluton and contains locally abundant molybdenite, scheelite and chalcopyrite in quartz veins (Stein et al., 1998). The first molybdenite + pyrite ${ }^{187} \mathrm{Re}^{187} \mathrm{Os}$ isochron age of $2778 \pm 5 \mathrm{Ma}$ for the Kuittila occurrence (Stein et al., 1998), which slightly overreaches the age of the hosting granitic rock (U-Pb zircon age of $2753 \pm 5 \mathrm{Ma}$; Nurmi \& Sorjonen-Ward) was impetus for re-examining decay constants and sampling protocols. In sum, Finland molybdenite occurrences, though the country has had nearly nothing in the way of Mo production, provided a complicated bedrock history that exposed early challenges in molybdenite dating (Stein, Geochemical Perspectives, in preparation).

The Paleoproterozoic Mo occurrences in Finland are associated with rocks formed in different stages of granitic magmatism, including pre-, synand post-orogenic granites. The research target of this study, the Kivilompolo Mo occurrence in the Peräpohja belt, is so far the only mineralization that is related to pre-orogenic felsic magmatism, being hosted by the pre-orogenic Kierovaara suite granite dated at $1989 \pm 6 \mathrm{Ma}$ (Ranta et al., 2015) (Fig. 1). The Mo-mineralized Paleoproterozoic granites of syn-orogenic age include the Susineva, Taipale, Lahnanen, Varparanta and Luukkolansaari Mo occurrences (Haapala \& Rämö, 2015, and references therein). The Tepasto Mo occurrence in the Central Lapland belt is associated with the postorogenic ca. 1.80 Ga Nattanen-type granites (e.g., Haapala et al., 1987; Heilimo et al., 2009; Haapala \& Rämö, 2015).

Paleoproterozoic supracrustal belts in northern and eastern Finland are characterized by the presence of orogenic gold deposits, which can be classified into Au-only deposits (e.g., Wyche et al., 2015) and deposits with an atypical metal association (Au-Co-Cu-U; e.g., Vanhanen, 2001; Vanhanen et al., 2015; Ranta et al., 2018; Molnár et al., 2019). The latter include, for example, the recently discovered Rompas Au- $\mathrm{U}$ mineralization and the Rajapalot Au-Co mineralization in the northern part of the Peräpohja belt (Fig. 2). The metal associations in these gold occurrences, which do not fit into traditional mineral deposit models, have provoked several studies focusing on the potential fluid and metal sources and the timing of ore-forming processes and their relationship 
to spatially associated granitoids (e.g., Molnár et al., 2016; Ranta et al., 2017; Molnár et al., 2017; Ranta et al., 2018). Widespread metal enrichment in Paleoproterozoic supracrustal rocks in Finland indicates circulation of metal-rich fluids of various sources and intermittent re-activation of deepseated structures over their ca. $600 \mathrm{Ma}$ depositional and deformational history, including the Svecofennian composite orogeny starting from ca. $1.92 \mathrm{Ga}$ and continuing into late- to post-orogenic times <1.80 Ga (e.g., Molnár et al., 2016, 2018).
This study revisits the Kivilompolo Mo deposit by reviewing the characteristics of the deposit based on Yletyinen (1967) in combination with the data collected during this study. In addition, we present new Re-Os ages for molybdenite and discuss the potential relationship between Kivilompolo Mo mineralization and the early uranium enrichment in the northern part of the Peräpohja belt, including that associated with the Rompas-Rajapalot Au-Co occurrences.
Figure 1. Simplified geological map of Finland modified after Haapala and Rämö (2015), Ranta et al. (2015), and Kärenlampi et al. (2019). Molybdenum occurrences are shown as red stars (taken from Haapala \& Rämö, 2015, and references therein). $\mathrm{Pb}=$ Peräpohja belt, $\mathrm{CLb}=$ Central Lapland belt.
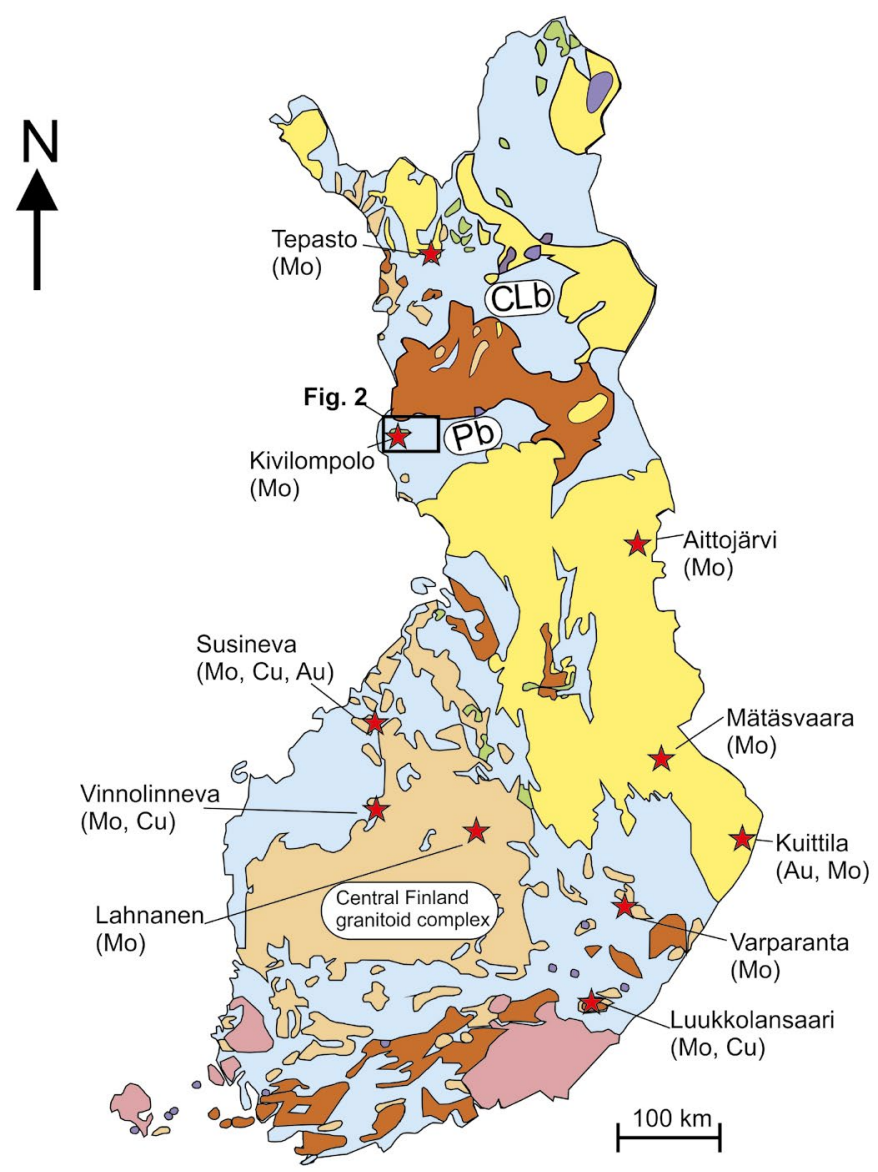

Archean undivided

\section{Proterozoic}

Preorogenic granite

Synorogenic granite

Lateorogenic granite
Mo occurrences

Postorogenic granite

Rapakivi granite Supracrustal rocks 


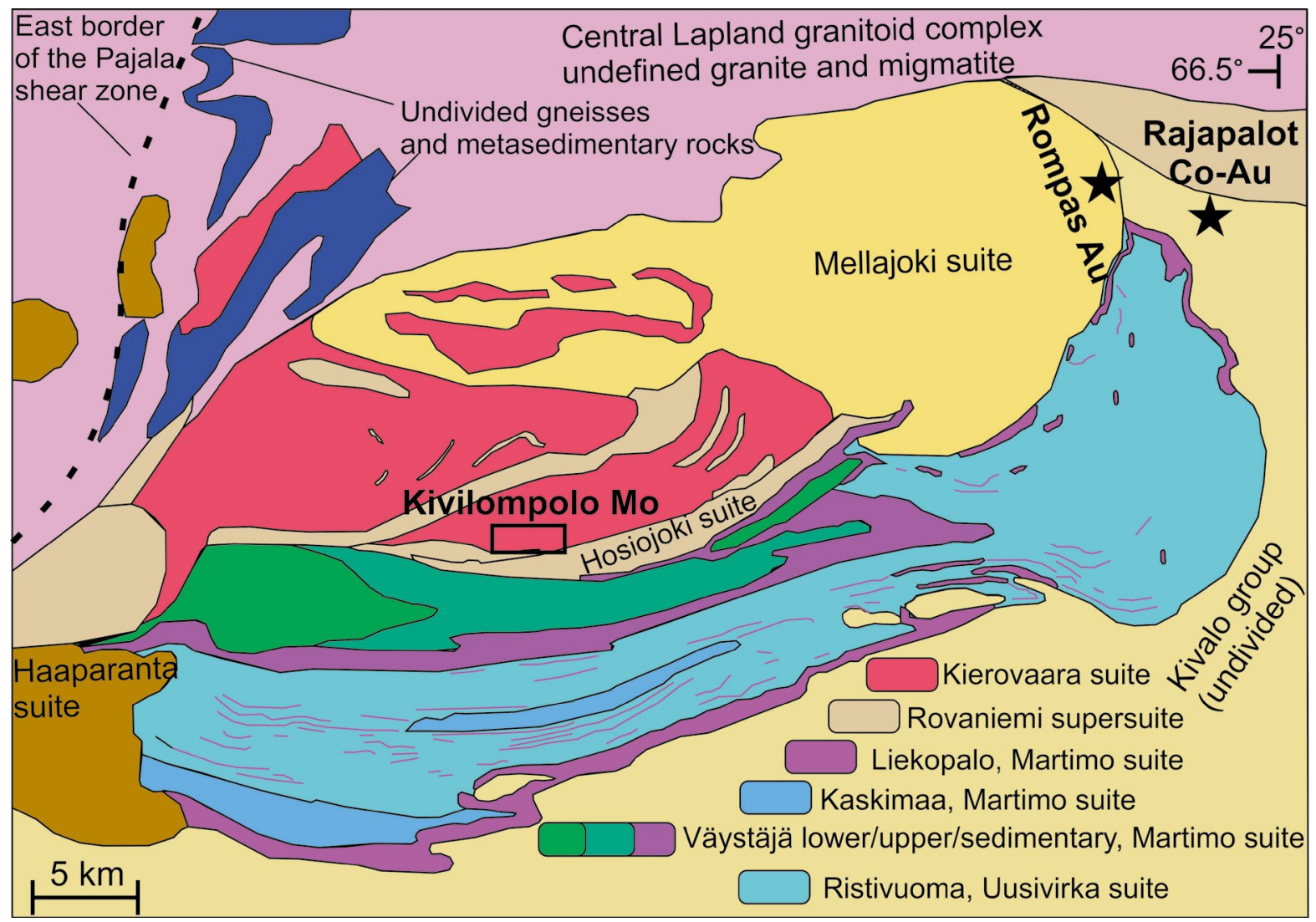

Figure 2. Simplified geological map of the north-western part the Peräpohja belt with the study area shown by a black rectangle, and black stars showing the locations and names of deposits discussed in the text (modified after Lahtinen et al., 2019).

\section{Regional geology}

The Peräpohja belt represents a typical Karelian volcano-sedimentary sequence, deposited on rifting Archean basement between ca. $2.44 \mathrm{Ga}$ and $1.88 \mathrm{Ga}$, as bracketed by the ages of mafic-layered intrusions in the Archean basement of the Peräpohja belt and syn-orogenic Haaparanta series monzonites (Huhma et al., 1990; Perttunen \& Vaasjoki; 2003; Iljina \& Hanski, 2005). The Peräpohja belt is bounded by the Central Lapland granitoid complex in the north and east and the Archean Pudasjärvi complex in the south. The N-S-trending Pajala shear zone separates the Peräpohja belt from the Norbotten craton in the west.

The Paleoproterozoic supracrustal rocks show an evolution of progressive rifting, varying from relatively mature siliciclastic and carbonate rocks and subaerial mafic volcanic rocks to deep-water turbiditic rocks. Perttunen et al. (1995) divided the Peräpohja belt into two major lithostratigraphical groups, known as the lower Kivalo group (2.44$2.06 \mathrm{Ga})$ and upper Paakkola group (2.06$1.88 \mathrm{Ga})$. The most recent stratigraphical division of the Kivalo group (2.38-2.10 Ga) was established by Kyläkoski et al. (2012) and is presented in Fig. 3. The lowermost unit, the Sompujärvi formation, comprises conglomerates lying on the Archean basement complex. The conglomerates are overlain by subaerial basalts of the Runkaus formation followed by quartzites of the Palokivalo formation. The minimum depositional age for these quartzites is determined by cutting mafic differentiated sills dated at ca. 2.22 Ga (Perttunen \& Vaasjoki, 2001; 
Hanski et al., 2010). The Petäjäskoski formation, deposited on the Palokivalo formation, is composed of siltstones, albitic schists, and carbonate rocks. The cutting ca. $2.14 \mathrm{Ga}$ Kuusivaara mafic sill provides a minimum depositional age for the Petäjäskoski formation (Kyläkoski et al., 2012; Huhma et al., 2018). It is overlain by continental flood basalts of the Jouttiaapa formation with a whole-rock Sm-Nd age of ca. $2105 \mathrm{Ga} \pm 50 \mathrm{Ma}$
(Huhma et al., 1990). The upper part of the Kivalo group comprises quartzites of the Kvartsimaa formation and a sequence of alternating dolomites and mafic tuffites assigned to the Tikanmaa, Poikkimaa, Hirsimaa, Rantamaa and Lamulehto formations. Karhu et al. (2007) published a zircon $\mathrm{U}-\mathrm{Pb}$ age of $2106 \pm 8 \mathrm{Ma}$ for the tuffites of the Hirsimaa formation.
Figure 3. Stratigraphic column of the Peräpohja belt (modified after Köykkä et al., 2019). Tectonic settings of the basin evolution (left of the diagram) and detailed discussions on the ages shown in this figure can be found from Köykkä et al. (2019) and references therein. Division of the Peräpohja belt into the Kivalo Group and upper lithodemic units after Lahtinen et al. (2015, 2019).

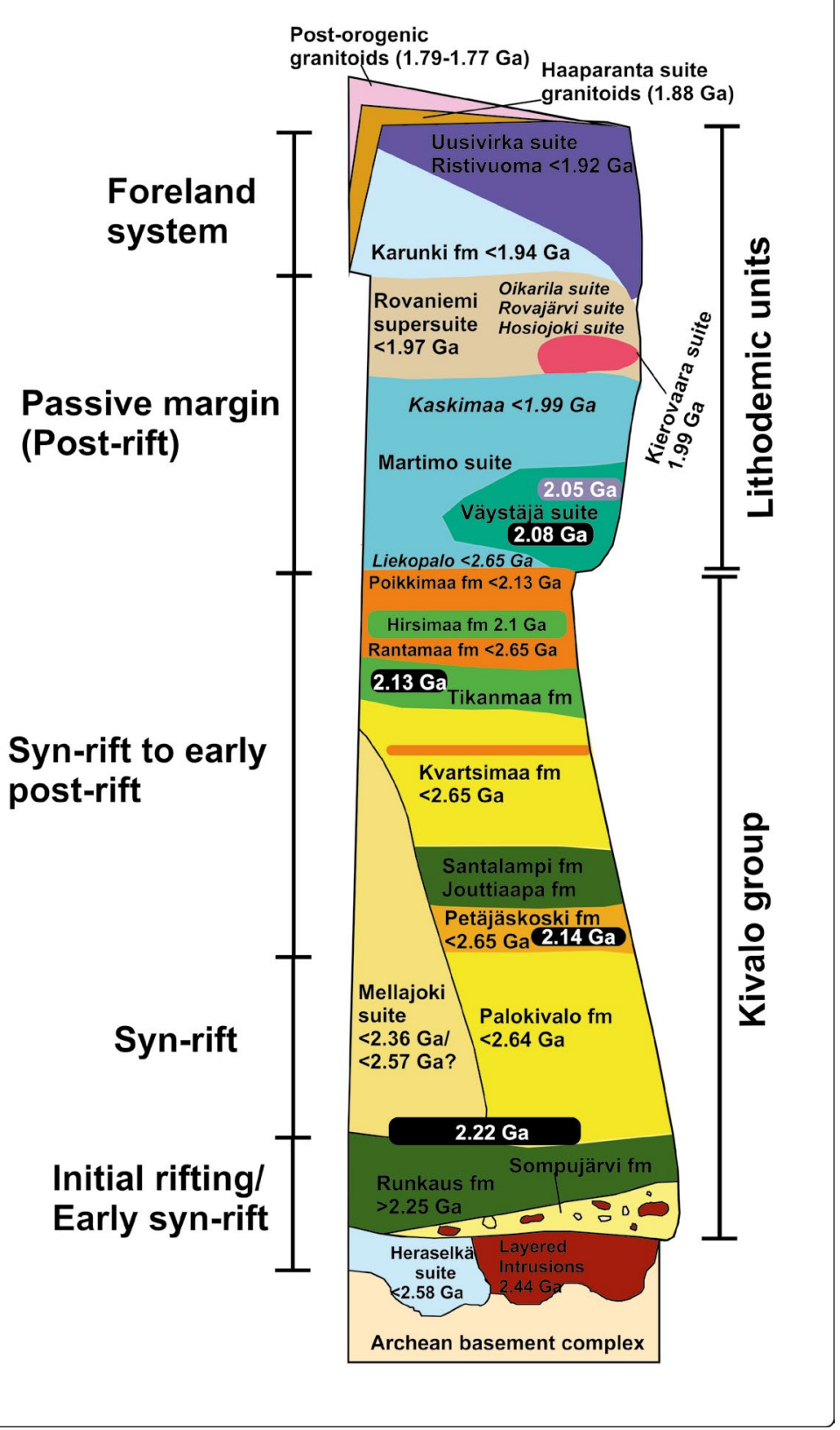


The lithological units in the northern part of the Peräpohja belt that were previously assigned to the Paakkola group have undergone complex thin-skin thrusting and show common type- 2 interference patterns, causing difficulties in applying the lithostratigraphical classification to them. Therefore, these rock units have recently been reclassified as lithodemic units (Bedrock of Finland - DigiKP; Lahtinen et al., 2015; Lahtinen et al., 2019) and separated from the Peräpohja belt sensu stricto. Figure 3 shows the latest stratigraphic column for the northern part of the Peräpohja belt, as constructed by Köykkä et al. (2019). The Heraselkä suite is composed of quartzite and paragneiss (e.g., Köykkä et al., 2019), and the Mellajoki suite consists mainly of quartzite, mica schist, and quartzfeldspar gneiss (Ranta et al., 2015). The Martimo suite constitutes autochthonous-parautochthonous lithodemic units of Liekopalo, Väystäjä and Kaskimaa (e.g., Lahtinen et al., 2015; Lahtinen et al., 2019). The Väystäjä lithodeme, composed of subaqueous mafic lavas, is intruded by a $2.08 \mathrm{Ga}$ mafic dike (Huhma et al., 2018) and a $2.05 \mathrm{Ga}$ felsic porphyry (Perttunen \& Vaasjoki, 2001). The Rovaniemi supersuite is a bimodal volcanic and partly epiclastic unit (e.g., Lahtinen et al., 2015; Köykkä et al., 2019) covering large areas in the western and central part of Lapland. It is divided into several suites (Hosiojoki, Rovajärvi, Oikarila; Lahtinen et al., 2019; Köykkä et al., 2019). The Ristivuoma metasedimentary rocks are part of the Uusivirka suite and contain psammites to thinly layered phyllites and paraschists (Lahtinen et al., 2019) with a maximum depositional age of 1.921.91 Ga (Lahtinen et al., 2015; Ranta et al., 2015).

The tectonic evolution of the Peräpohja belt has commonly been attributed to basement rifting followed by formation of a fold and thrust belt (e.g., Lahtinen et al., 2015; Nironen, 2017; Köykkä et al., 2019). In contrast, Piippo et al. (2019) suggested development of strike-slip faults during active rifting and pull-apart basin development with an emphasis on the underlying Archean basement topography and its architecture (e.g., basement faults) controlling structures in the overlying volcano-sedimentary cover during deformation. Köykkä et al. (2019) proposed five regionally correlative (Peräpohja, Kuusamo and Central Lapland belts) basin evolution stages between ca. 2.5 and $1.88 \mathrm{Ga:}$ (1) initial rifting/early syn-rift, (2) syn-rift, (3) syn-rift to early post-rift, (4) passive margin (post-rift), and (5) foreland system.

Lahtinen et al. (2015) described up to five deformation stages in the youngest metasedimentary formation of the Peräpohja belt (Martimo suite). The earliest deformation stage D1 $(\leq 1.91 \mathrm{Ga})$ generated a NS-trending S1 fabric and recumbent folds due to east-directed thin-skinned thrusting. NS-directed shortening in stage D2 (1.90-1.89 Ga) produced EW-trending folds and a pervasive, steeply dipping foliation. Stage D3 $(1.88-1.87 \mathrm{Ga})$ is represented by NNW- and WNW-trending, heterogeneously developed structural trends. Traces of the D4 deformation $(1.83-1.81 \mathrm{Ga})$ are most prominently seen as NNE-trending lineaments in aeromagnetic images. The last deformation stage (D5, 1.79-1.77 Ga) is characterized by WSWshortening.

Subsequent to deposition and metamorphism of supracrustal rocks, at least four episodes of felsic to intermediate plutonism have been recognized in the Peräpohja belt: (1) the 1.99-2.0 Ga strongly flattened gneissic porphyritic Kierovaara granite (the Kierovaara granite suite) (Ranta et al., 2015; Lahtinen et al., 2019), (2) the ca. $1.88 \mathrm{Ga}$ syn-orogenic Haaparanta suite granitoids, found especially in the eastern part of the belt, (3) the ca. 1.80 Ga appinitic plutons (Tainio, 2014), and (4) the 1.79-1.77 Ga late-orogenic granitoids, including tourmaline-rich pegmatitic granites (e.g., Ranta et al., 2015).

\section{Sampling and analytical methods}

Mapping and sampling in the study area was conducted as part of an MSc project (Goode, 2019). Detailed petrography and mapping results are reported in Goode (2019). Samples representing the mineralized quartz veins and hosting granitic 
rocks were collected from the Kahvikallio outcrop area with a portable diamond saw. Two channels of approximately 1 meter each long were sampled, with their locations having been chosen so that they intersect the main mineralized veins but also sample the hosting granitic rock. In addition, grab samples were collected from an area covering approximately $1 \times 2 \mathrm{~km}$ around the Kahvikallio outcrop. Wholerock trace element analyses were conducted by Bureau Veritas Commodities Canada Ltd in Vancouver, Canada, using lithium borate fusion and inductively coupled plasma mass spectrometry (ICP-MS). The analyzed elements include $\mathrm{Hf}, \mathrm{Nb}$, Rb, Sn, Sr, Ta, Th, U, V, W, Zr, Y, La, Nd, Sm, Eu, Gd, Lu, Mo, Cu, Pb, Zn, Ni, As, Bi, Ag, and Se.

Samples for the whole-rock major element analysis were collected from the drill cores of GTK by Pyhäsalmi Mine Oy in 2009. Analyses were conducted by Labtium Oy using X-ray fluorescence (XRF) on pressed pellets (Labtium Oy method 175X). The measurements include major elements $\mathrm{Si}, \mathrm{Ti}, \mathrm{Al}, \mathrm{Fe}, \mathrm{Mn}, \mathrm{Mg}, \mathrm{Ca}, \mathrm{Na}, \mathrm{K}$, and $\mathrm{P}$, and trace elements As, Ba, Bi, Ce, Cl, Cr, Cu, Ga, La, Mo, Nb, $\mathrm{Ni}, \mathrm{Pb}, \mathrm{Rb}, \mathrm{S}, \mathrm{Sb}, \mathrm{Sc}, \mathrm{Sn}, \mathrm{Sr}$, Th, U, V, Y, Zn, and Zr.

The molybdenite sample from the Kahvikallio outcrop selected for Re-Os dating was obtained from the Geological Museum of the University of Oulu. The hand-drilled mineral separate was 100\% molybdenite. Two aliquots of 11.2 and $28.2 \mathrm{mg}$ were analyzed. Re-Os isotopic data were acquired using a Carius tube dissolution with sample-spike equilibration with a mixed Re-double Os spike (Markey et al., 2003). Rhenium and Os isotopic ratios were measured using negative thermal ionization mass spectrometry (N-TIMS) at the AIRIE Program, Colorado State University.

\section{The Kivilompolo Mo occurrence}

The Kivilompolo Mo occurrence is located in the northwestern part of the Peräpohja belt, approximately $20 \mathrm{~km}$ from the belt's contact to the Central Lapland granite complex (Fig. 2). Soon after layman prospectors had sent molybdenumbearing boulders from the Kivilompolo area to the Geological Survey of Finland (GTK) in the early 1950 's, GTK workers were able to locate the source of the boulders near Lake Iso Kallijärvi in an outcrop called Kahvikallio, and started a diamond-drilling program at the location, with the total number of drill holes amounting to 33 . The first description of the Mo occurrence and the results from the drilling campaign were reported by Yletyinen (1967).

The mineralization is hosted by porphyritic granite of the Kierovaara granite suite, about $1.5 \mathrm{~km}$ from the southern contact between granite and the Hosiojoki suite felsic gneisses (Fig. 3). The Kierovaara magmatic suite is approximately $30 \mathrm{~km}$ in length and $10 \mathrm{~km}$ in width and displays a K-feldspar-porphyritic augen gneiss texture and contains abundant paraschist and meta-arkosequartzite enclaves (Perttunen \& Hanski, 2003; Lahtinen et al., 2019). The Kierovaara granite has yielded a U-Pb zircon age of $1989 \pm 6 \mathrm{Ma}$ (Ranta et al., 2015). While the Kierovaara suite is clearly plutonic in origin, the Hosiojoki felsic suite is ambiguous due to the absence of primary magmatic structures in its feldspar gneisses; the rocks may be sedimentary, volcanic or volcaniclastic in origin (Lahtinen et al., 2019). In-situ dating using multicollector ICPMS reveals a homogeneous zircon population with an age ca. $1.99 \mathrm{Ga}$, which equals the age of the Kierovaara granite suite (op.cit.).

The host rock for the Kivilompolo mineralization is gneissic porphyritic granite of the Kierovaara granite suite (Fig. 3) with its color ranging from red to gray, similar to the main rock type of the Kierovaara granite suite (Fig. 4). The foliation strikes roughly NE-NNE and dips $50^{\circ}-60^{\circ}$ to SE. Locally, the granite contains biotite-hornblenderich stripes. Sericitization is the most common alteration in the granites. Boudinaged quartz veins hosting the main part of the molybdenite mineralization are found as individual veins or as vein networks and are subparallel to the foliation of the granite. Sulfides are comprised of molybdenite, pyrite, and chalcopyrite with minor pyrrhotite 

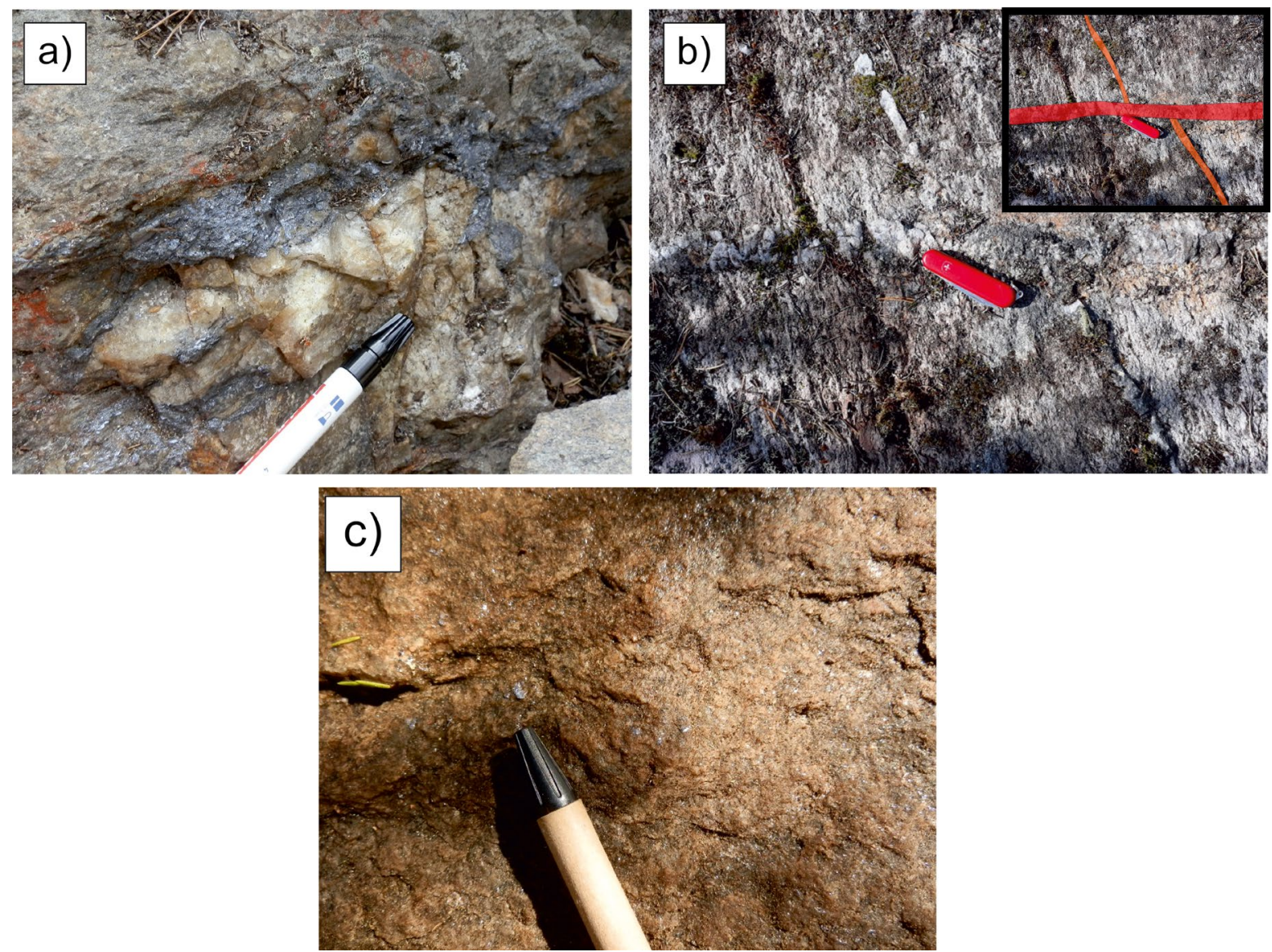

Figure 4. Photographs from the main Kahvikallio outcrop. a) Coarse-grained molybdenite in a quartz vein subparallel to foliation. b) Younger quartz vein (no molybdenite) almost perpendicular to the foliation crosscuts deformed mineralized quartz-molybdenite veins subparallel to the foliation. c) Disseminated molybdenite grains in sericitized granite. Marker pens and pocket knife shown as scales (approximately $5 \mathrm{~cm}$ in length).

locally. Drilling shows that mineralized veins continue to a depth of at least $150 \mathrm{~m}$. Yletyinen (1967) reports that the overall area with anomalous molybdenite in outcrops or in boulders is oriented roughly EW and is approximately $900 \mathrm{~m}$ wide and $3 \mathrm{~km}$ long. However, the real dimensions of the mineralized area are hard to evaluate due to limited surface exposure. Furthermore, correlation of the boudinaged quartz veins between drill holes is challenging.

In this study, outcrop samples were collected from the main Kahvikallio outcrop area. In these samples, several generations of quartz veins are present. The most common veins are typically foliation-concordant and partially boudinaged, displaying several stages of deformation (Fig. 4a). Vein thicknesses vary from $1-2 \mathrm{~cm}$ up to $1 \mathrm{~m}$. A younger NS-trending set of quartz veins without molybdenite crosscut the foliation at a high angle (Fig. 4b) and show no evidence for deformation.

Molybdenite in quartz veins is typically coarsegrained, with some crystals reaching more than $3 \mathrm{~cm}$ in size Fig. 4a). Locally, molybdenite occurs as disseminated grains within the host granitic rock (Fig. 4c). The sulfide mineralogy is simple, comprising molybdenite, pyrite, and chalcopyrite. Minor amounts of magnetite and ilmenite are present, with ilmenite occurring as rims around magnetite. Abundant coarse sulfides are only found in association with quartz veins. Sericite is locally 
abundant in the host rock and the alignment of fine-grained sericite and biotite often defines the foliation. Chloritization of biotite is common.

The grey granite is similar in mineral composition to the red granite, though typified by a lower proportion of K-feldspar, biotite and sericite, and a higher quartz content. Sulfides are present in the grey granite but are less abundant than in the red granite. The lower amount of molybdenite is manifested in molybdenite's occurrence as finegrained disseminations within the gray granite.
The drill core loggings of the Kahvikallio outcrop area (12 drill cores; Yletyinen, 1967 and references therein) were digitized and based on these loggings, the occurrence of mineralized quartz veins was modelled using the Leapfrog GEO 3D-modelling software (Fig. 5). The loggings do not contain any structural measurements and therefore, the dip of the veins is based on the description of Yletyinen (1967) and interpreted correlations of quartz veins between drill holes. As illustrated in Figure 5, the mineralized quartz veins are steeply dipping to the SE.

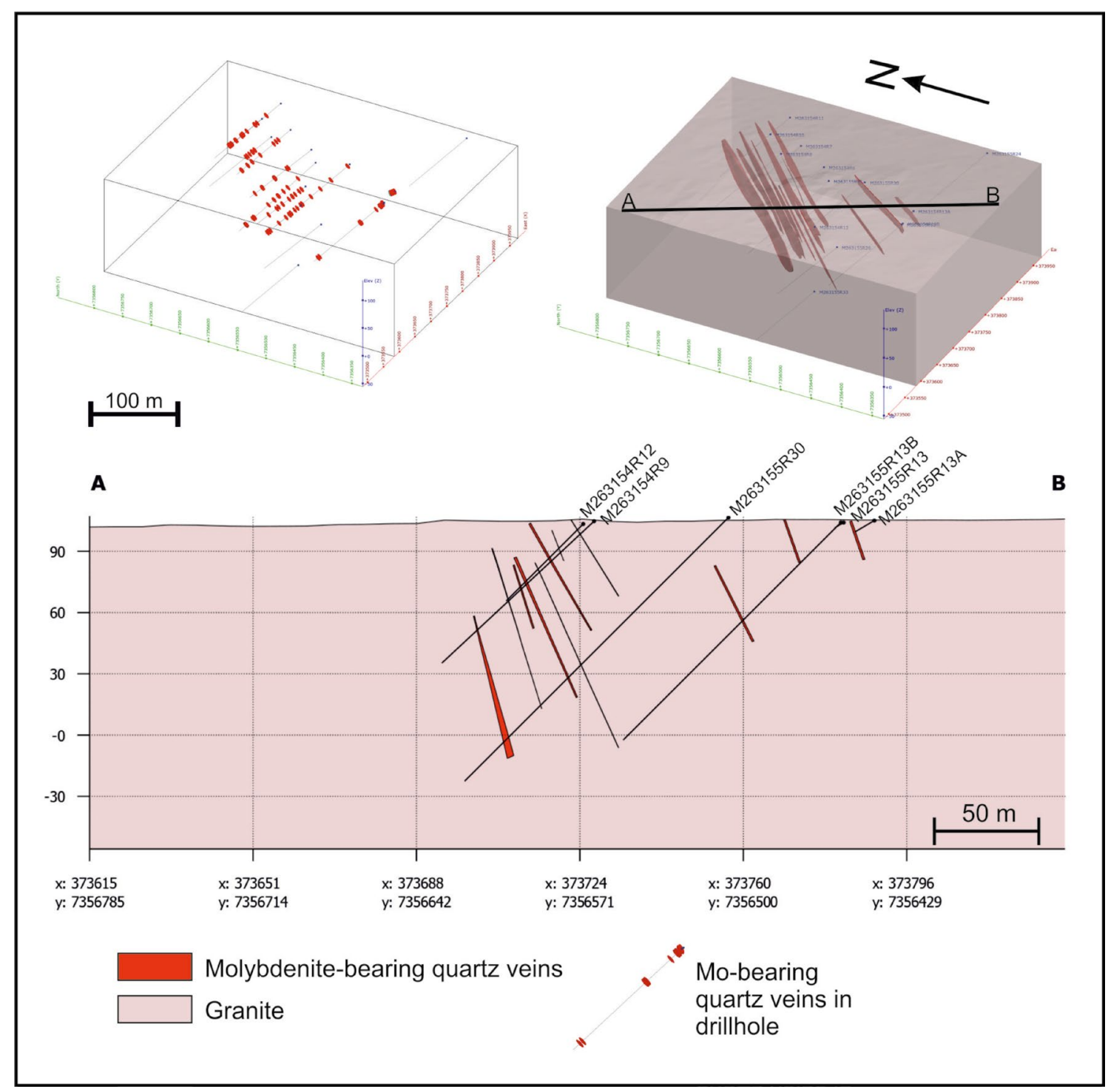

Figure 5. 3D-model of the molybdenite-bearing quartz veins in the main mineralized outcrop area (Kahvikallio) at Kivilompolo. Coordinates are shown in ETRS-TM35FIN system. 
Table 1. Average composition of major element analysis of the Kivilompolo granitic rocks

\begin{tabular}{lcccc}
\hline & Red Kivilompolo granite (n=32) & Stdev $(n=32)$ & Grey Kivilompolo granite $(n=17)$ & Stdev $(n=17)$ \\
\hline SiO2 (wt\%) & 73,7 & 0,8 & 74,0 & 2,0 \\
Al2O3 & 13,3 & 0,4 & 13,1 & 1,0 \\
$\mathrm{Fe} 203$ & 2,8 & 0,7 & 2,8 & 1,0 \\
$\mathrm{CaO}$ & 0,5 & 0,2 & 0,5 & 0,2 \\
$\mathrm{MgO}$ & 0,7 & 0,1 & 0,9 & 0,4 \\
$\mathrm{Na20}$ & 3,5 & 0,8 & 2,6 & 1,1 \\
$\mathrm{~K} 20$ & 4,7 & 0,8 & 5,0 & 1,1 \\
$\mathrm{TiO} 2$ & 0,3 & 0,0 & 0,3 & 0,0 \\
$\mathrm{MnO}$ & 0,04 & 0,01 & 0,05 & 0,02 \\
P2O5 & 0,1 & 0,0 & 0,1 & 0,0 \\
S & 0,2 & 0,2 & 0,3 & 0,4 \\
Total & 99,7 & & 99,5 &
\end{tabular}

\section{Geochemistry of the Kierovaara suite granites}

The complete whole-rock major and trace element results are listed in Electronic Appendix A. Average major element compositions of the red and grey granite samples in which no post-emplacement alteration (e.g., sericitization) is observed are shown in Table 1. The same filtering has been applied to samples in the subsequent geochemical plots (Figs. 6 and 7). Chemically, there are no distinct differences between the red and white granite at Kivilompolo and thus they are not separated in the major and trace element plots.

In Figures 6a-c, chemical compositions of granitic rocks from the Kivilompolo Mo-bearing area are plotted in diagrams used to classify igneous rocks. Also, for comparison, shown are compositions of other granites from the Kierovaara suite and felsic gneisses of the Hosiojoki suite. In terms of major elements, the intrusive rocks from the Kivilompolo area (red and grey granites) are mostly calc-alkaline to alkali-calcic, peraluminous alkali-feldspar granites (Figs. 6a-c). They do not differ from the Kierovaara suite granite samples analyzed farther from Kivilompolo. In contrast, the Hosiojoki suite rocks seem to be higher in normative $\mathrm{An} /(\mathrm{An}+\mathrm{Or})$ and consequently are classified as syenogranites and monzogranites instead of alkali-feldspar granites.
Lithophile trace element data for granites from the Kivilompolo are shown in Figures $7 \mathrm{a}-\mathrm{c}$. In the granitoid discrimination diagrams (Pearce et al., 1983), the samples from Kivilompolo straddle the boundary between the fields of volcanic arc granitoids (VAG) and syn-collisional granitoids (syn-COLG) (Fig. 7a). The $\mathrm{Nb}$ and Sr concentrations are low, around $10 \mathrm{ppm}$ and 30 ppm, respectively. The chondrite-normalized rareearth element patterns of the granite samples from the Kivilompolo area are characterized by significant enrichment in LREE with $(\mathrm{La} / \mathrm{Sm})_{\mathrm{N}}$ ratios of 5.98.3, strong negative $\mathrm{Eu}$ anomalies $\left(\mathrm{Eu} / \mathrm{Eu}^{*}=0.39\right.$ 0.71), and relatively flat HREE sections (Fig. 7b). In the primitive mantle-normalized spidergram (Fig. 7c), the rocks are characterized by strong enrichment in $\mathrm{Rb}, \mathrm{U}$, Th and LREE, while $\mathrm{Ba}, \mathrm{Sr}$, and $\mathrm{Nb}$ show distinct negative anomalies relative to the neighboring elements.

The molybdenum content varies greatly between the Kivilompolo sample types, being generally $<100 \mathrm{ppm}$ in the granite samples, whereas in the mineralized quartz veins, it can locally be as high as $>10000 \mathrm{ppm}$. There is no clear evidence for the presence of a halo of higher Mo in the host rock around the veins. The $\mathrm{Cu}$ content in the mineralized quartz veins is between 100-300 ppm, with the exception of one erratic outlier of $594 \mathrm{ppm}$ (102 ppm Mo). 
a)

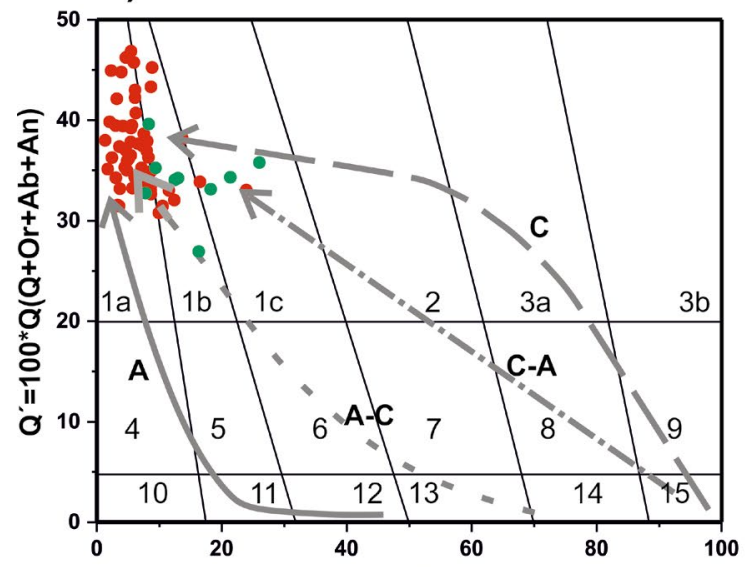

c)

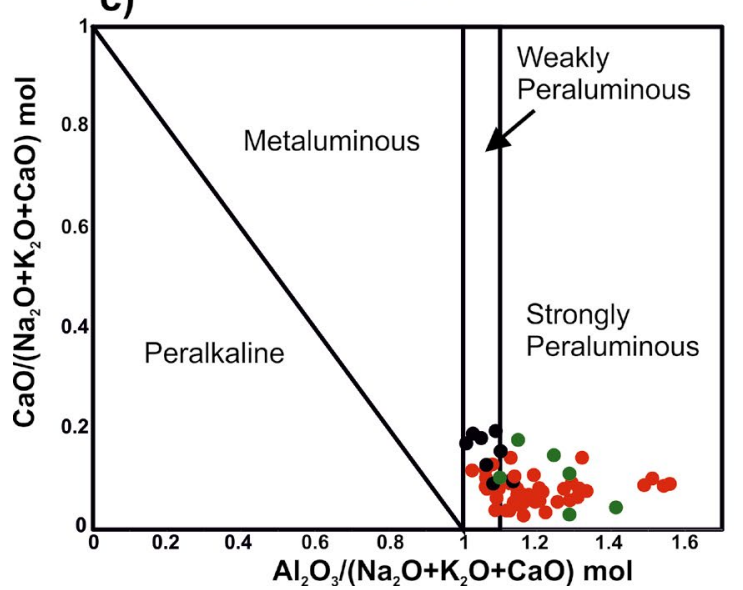

b)

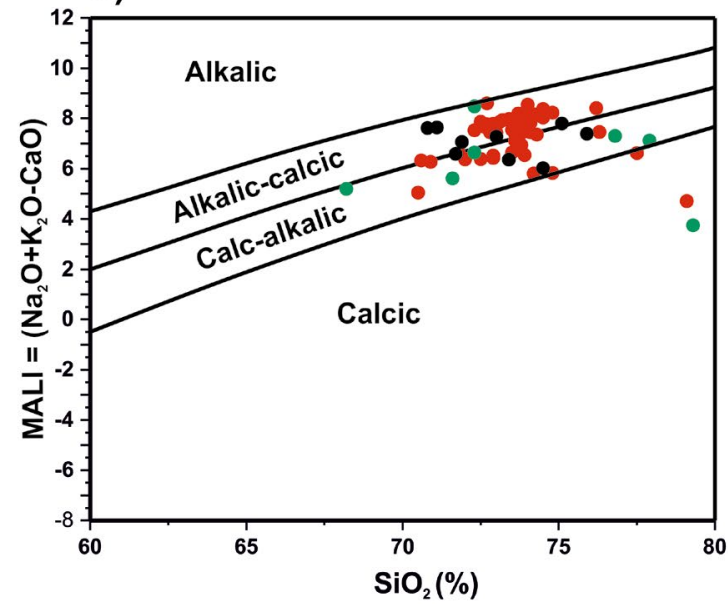

C - Calcic

C-A - Calc-alkalic

A-C - Alkali-calcic

A - Alkalic

1a: Alkali-feldspar granite

1b: Syenogranite

1c: Monzogranite

2: Granodiorite

3a: Tonalite

3b: Calcic-tonalite

4: Alkali-feldspar quartz syenite

5: Quartz syenite

6: Quartz monzonite

7: Quartz monzodiorite

8: Quartz diorite

9: Quartz gabbro

10: Alkali-feldspar syenite

11: Syenite

12: Monzonite

13: Monzogabbro

14: Diorite

15: Gabbro

Figure 6. Major element diagrams for granite samples from the Kivilompolo Mo occurrence. Data from the Kierovaara suite and Hosiojoki suite (Ranta et al., 2015; Lahtinen et al., 2019) are plotted as reference. a) Q-ANOR normative classification diagram after Streckeisen and LeMaitre (1979). ANOR $=100 * A n /(O r+A n) . b)$ Modified alkali-lime index $\left(\mathrm{MALI}=\mathrm{Na}_{2} \mathrm{O}+\mathrm{K}_{2} \mathrm{O}-\right.$ $\mathrm{CaO})$ vs. $\mathrm{SiO}_{2}$ after Frost et al. (2001). c) Alumina saturation diagram after Barton and Young (2002).

\section{Re-Os dating of molybde nite from Kivilompolo}

Re-Os dating of molybdenite is based on the beta decay of $187 \mathrm{Re}$ to $187 \mathrm{Os}$ with a half-life about 10 times the age of the Earth (Stein et al. 2001). Uniquely, molybdenite does not take in Os on crystallization, but readily substitutes Re for Mo in its structure. Molybdenite retains its primary age through metamorphism as long as the system remains reduced (Bingen and Stein, 2003).

In this study, the Re-Os ages for the Kivilompolo molybdenite sample are presented in Table 2. Two replicate analyses of the same powdered molybdenite sample yielded Re concentrations of $49.13 \mathrm{ppm}$ and $54.72 \mathrm{ppm}$ and ${ }^{187}$ Os concentrations of $1047 \mathrm{ppb}$ and $1167 \mathrm{ppb}$. The double Os spike detected no common Os. Re-Os ages of $2001 \pm 8 \mathrm{Ma}$ and $2003 \pm 7 \mathrm{Ma}$ were obtained, in excellent agreement within their 2-sigma analytical uncertainty. The Os in molybdenite nearly always $100 \%$ radiogenic $\left({ }^{187} \mathrm{Os}\right)$ and thus the assumed value for an initial ${ }^{187} \mathrm{Os} /{ }^{188} \mathrm{Os}$ does not have an impact on the age calculation (Stein, 2014). The Kivilompolo molybdenite, with no common Os detected, is an exemplary molybdenite in this regard. 
a)

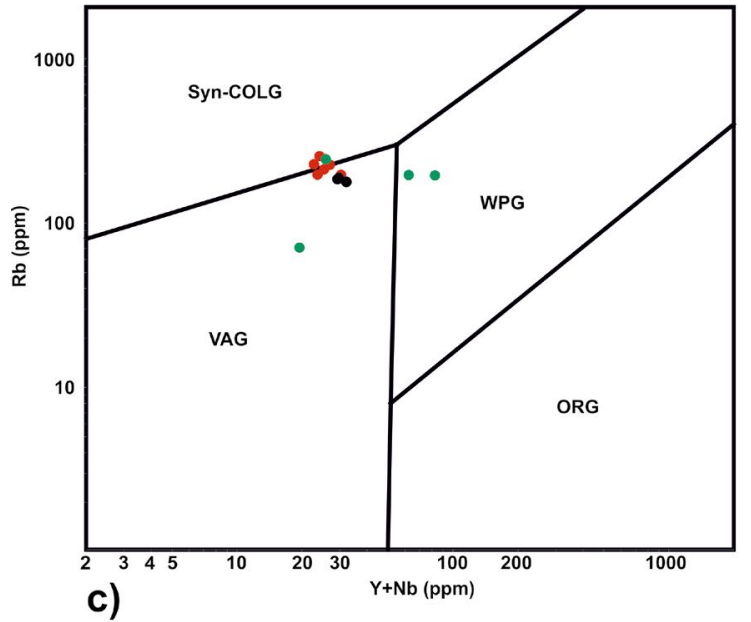

b)

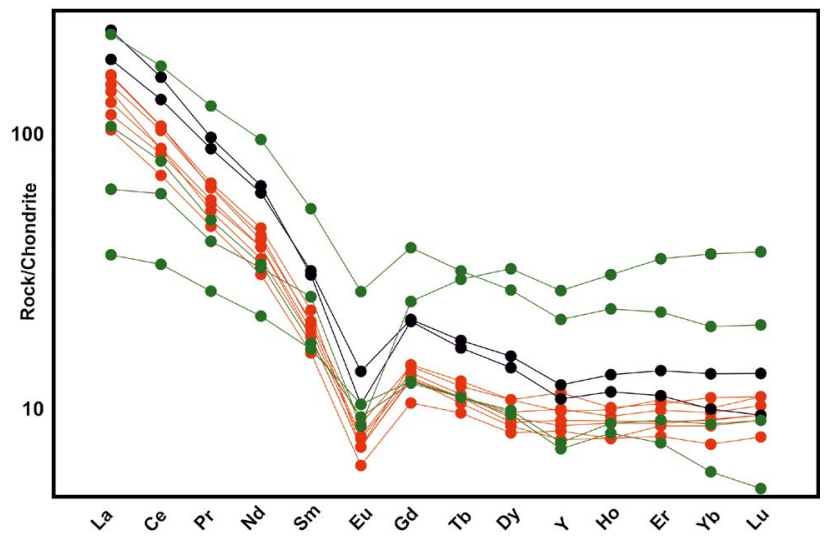

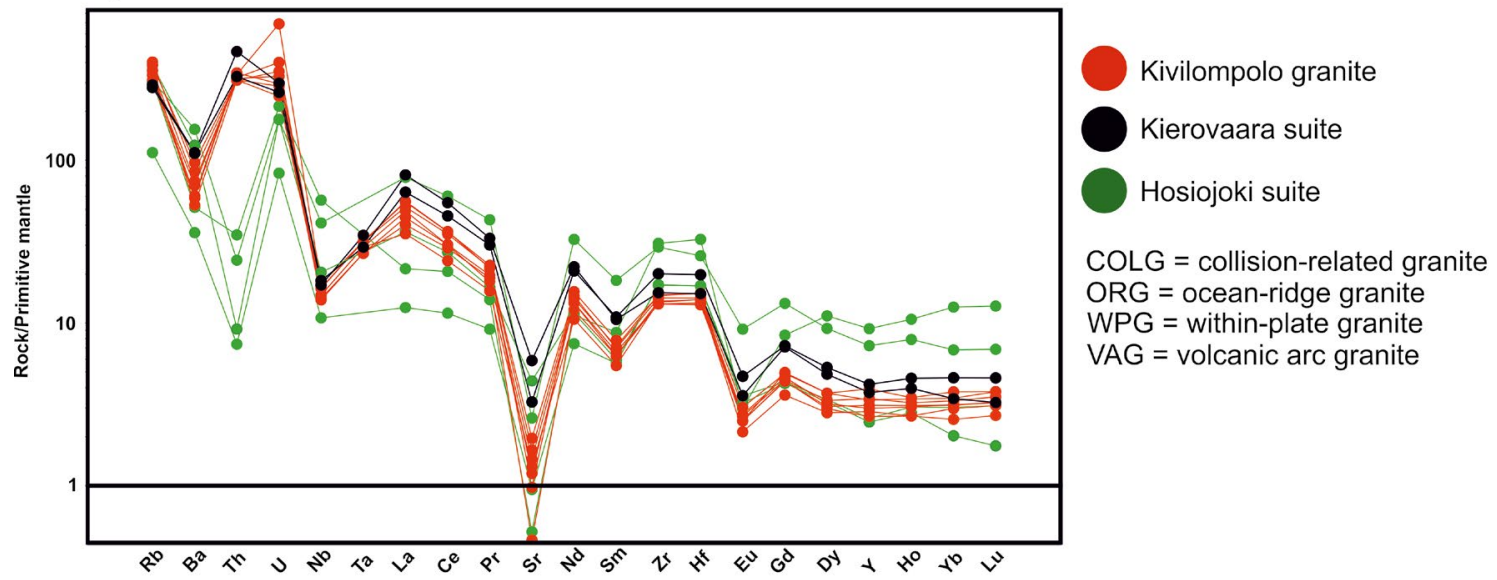

Figure 7. Lithophile trace element diagrams for granite samples from the Kivilompolo occurrence. Data from the Kierovaara suite and Hosiojoki suite (Ranta et al., 2015; Lahtinen et al., 2019) are plotted as reference. a) Granitoid discrimination diagrams after Pearce et al. (1984). b) Chondrite-normalized REE patterns. Normalization values after Sun and McDonough (1989). c) Primitive mantle-normalized spidergrams. Normalization values after Sun and McDonough (1989).

Table 2. Re-Os data for molybdenite from the Kivilompolo Mo occurrence.

\begin{tabular}{|lccccccc|}
\hline AIRIE Run \# & $\begin{array}{c}\text { Sample } \\
\text { Number }\end{array}$ & $\mathbf{R e}(\mathbf{p p m})$ & Re error (ppm) & 187 $\mathbf{O s ~ ( p p b ) ~}^{\text {187 } \text { Os error, (ppb) }}$ & Age (Ma) & Abs error (Ma) \\
\hline MD-1436 & E295 & 49,13 & 0,09 & 1047,01 & 0,84 & 2001 & 8 \\
MD-1437 & E295 & 54,72 & 0,07 & 1167,04 & 0,93 & 2003 & 7 \\
\hline
\end{tabular}

Re and Os isotopic ratios were measured using negative thermal ionization mass spectrometry (NTIMS) at the AIRIE Program, Colorado State University.

Ages reported include the decay constant uncertainty for ${ }^{187} \mathrm{Re}$, so they can be directly compared with U-Pb ages; concentration and age uncertainties all at 2-sigma.

Re blank $=3.184 \pm 0.039 \mathrm{pg}$, Os blank $=0.174 \pm 0.012 \mathrm{pg}$ with ${ }^{187} \mathrm{Os} /{ }^{188} \mathrm{Os}=0.313 \pm 0.017$; blank corrections have no effect on the age calculation for these analyses. 


\section{Discussion}

\subsection{Characterization of the Kivilompolo Mo occurrence}

Around 95\% of world's molybdenum is sourced from porphyry type deposits (e.g. Sinclair, 2007) and about $50 \%$ of it come from porphyry $\mathrm{Cu}$ deposits (e.g., Sillitoe, 2010). Porphyry deposits represent large magmatic-hydrothermal systems, which have affected $10 \mathrm{~s}$ to $>100 \mathrm{~km}^{3}$ of upper crustal rocks, resulting in mass redistribution and concentration of a suite of elements (e.g., Sillitoe, 2010). Porphyry Mo deposits are generally divided into two end-members, the arc-related type and alkali-feldspar-rhyolite-granite type (or Climax type) (e.g., Ludington et al., 2009; Ludington and Plumlee, 2009; Taylor et al., 2012). These two deposit types occur in different tectonic settings and have different host-rock compositions.

Arc-related porphyry Mo deposits form in the same in convergent margin tectonic environment above subduction zones as many porphyry copper deposits, but they are thought to form at a deeper crustal level because of the difference in the behavior of $\mathrm{Mo}$ and $\mathrm{Cu}$ in magmatic systems (e.g., Sillitoe, 2010). Arc-related Mo deposits are hosted by porphyritic intermediate to felsic (65-77 wt.\% $\mathrm{SiO}_{2}$; Taylor et al., 2012) calcalkaline granitoid plutons, which are genetically, temporally and spatially associated with molybdenite mineralization. The granitic rocks in the Kivilompolo area are highly siliceous with $\mathrm{SiO}_{2}$ between 70 and 79 wt.\%. Arc-related felsic rocks hosting porphyry-type deposits commonly show highly fractionated REE patterns with $\mathrm{La} / \mathrm{Yb} \geq 20$, a flat HREE-part of the spectra, and Sr contents above $100 \mathrm{ppm}$ leading to high $\mathrm{Sr} / \mathrm{Y}$ ratios ( $\geq 20$ ) (e.g., Richards, 2011). The granitic rocks at Kivilompolo display LREE enrichment and flat HREE patterns with $\mathrm{La} / \mathrm{Yb}$ ratio around 20 (Fig. 7b). However, the Sr contents are low, ranging from around 10 to $40 \mathrm{ppm}$, and $\mathrm{Sr} / \mathrm{Y}$ ratio is very low, around 2, which are not consistent with the composition of a typical host rock of arc- related porphyry deposits. Similarly, the negative $\mathrm{Eu}$ anomalies of the Kivilompolo samples are atypical for arc-related porphyry deposits, which normally display weak or negligible negative $\mathrm{Eu}$ anomalies due to the high water content of the arcrelated magmas and the consequent suppression of crystallization of plagioclase relative to that of hornblende (e.g., Richards, 2011 and references therein). In arc-related porphyry Mo deposits, the associated intrusive rocks usually show relatively low $\mathrm{Rb}$ and $\mathrm{Nb}$ concentrations, around $300 \mathrm{ppm}$ and $30 \mathrm{ppm}$, respectively (Taylor et al., 2012). Samples from Kivilompolo show $\mathrm{Rb}$ and $\mathrm{Nb}$ concentrations around $220 \mathrm{ppm}$ and $10 \mathrm{ppm}$, respectively.

The alkali-feldspar-rhyolite-granite-type Mo porphyry deposits (Climax-type) are typically formed in back-arc extensional to trans-tensional zones and rift zones (John and Taylor, 2016, and references therein). They are commonly hosted by highly evolved, A-type granites (e.g., Ludington and Plumlee, 2009), with their trace element signature being characterized by high $\mathrm{Rb}(>250 \mathrm{ppm})$ and $\mathrm{Nb}(>20 \mathrm{ppm})$ contents coupled with low $\mathrm{Zr}$ concentrations (<120 ppm; Ludington and Plumlee, 2019). The analyzed granite samples from Kierovaara have average $\mathrm{Rb}$ and $\mathrm{Nb}$ contents of $220 \mathrm{ppm}$ and $10 \mathrm{ppm}$, respectively, and $\mathrm{Zr}$ averages $150 \mathrm{ppm}$. Strontium concentrations in the Climax-type porphyry deposits are usually well below 100 ppm (Taylor et al., 2012), which is similar to values found in the Kivilompolo granites (avg. 30 ppm). Typically, the host granitoids of the Climax-type deposits show a high fluorine content, up to $1 \mathrm{wt} \%$ (Ludington and Plumlee, 2009). We do not have data for $\mathrm{F}$, but based on the signature of other trace elements, the Kierovaara granite does not resemble the host-rocks of Climax-type porphyry deposits. Figure 8 compares primitive mantle-normalized spidergrams for granites from the Kivilompolo, host rocks for the Arc-related MAX porphyry Mo deposit (Lawley et al., 2010), and the Climax-type Shapinggou Mo deposit (Zhang et al., 2014). Furthermore, REE pattern from the classical Climax-type deposits from 


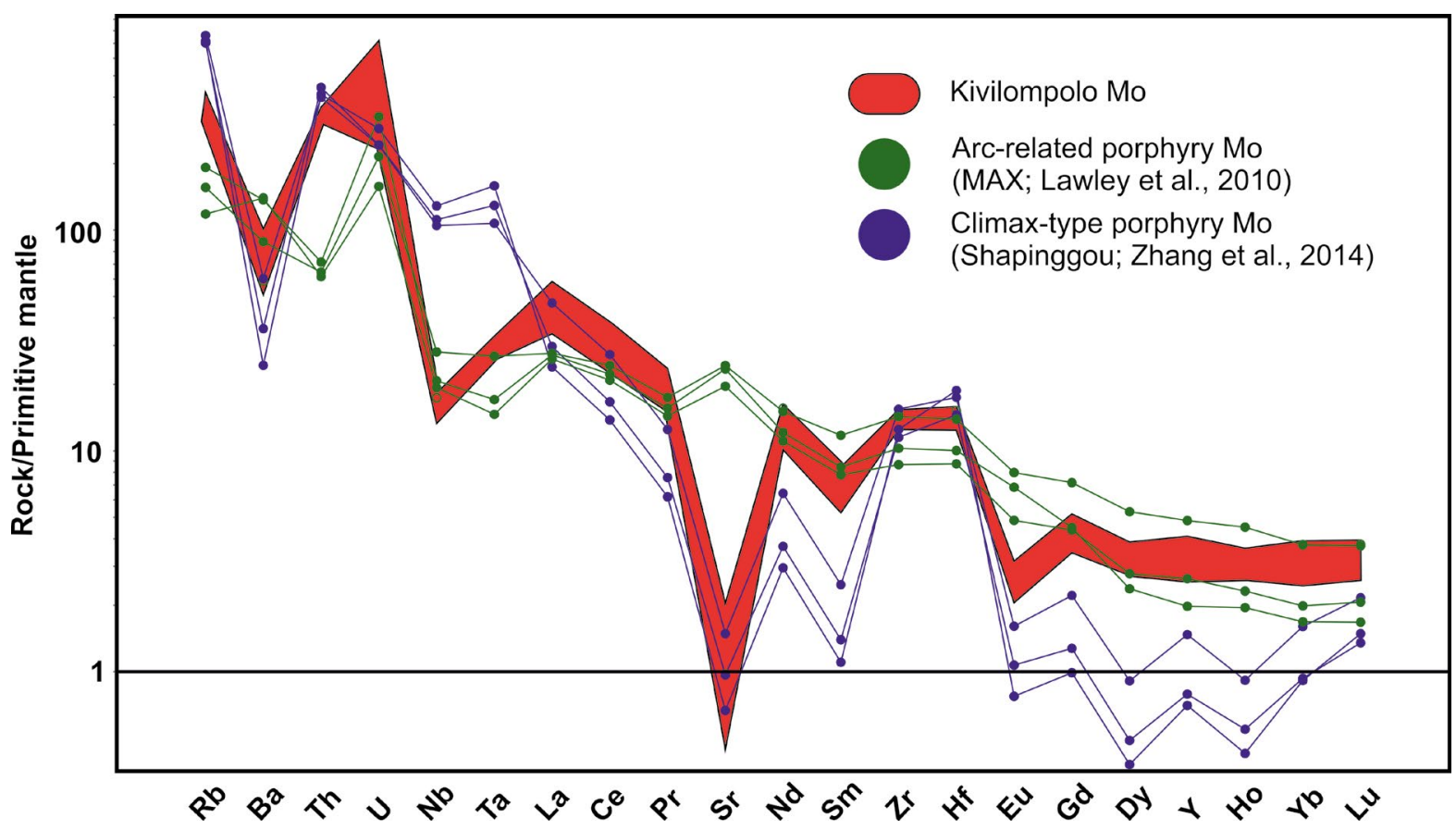

Figure 8. Primitive mantle-normalized spidergrams for granites associated with the Kivilompolo Mo occurrence and granites from arc-related porphyry Mo deposits (Lawley et al., 2010) and Climax-type porphyry Mo deposits (Zhang et al., 2014). Normalization values after Sun and McDonough (1989).

Colorado Mineral Belt display U-shaped pattern with strong negative Eu-anomaly (Stein, 1988) which do not characterize Kivilompolo. Regarding the genesis of the Kivilompolo Mo occurrence, it seems not to fit into either classical member of the porphyry family. However, given the tectonic setting during the pre-orogenic rifting of the basin at ca. 2.0 Ga, the Kivilompolo resembles more closely the Climax-type porphyry deposits than arc-related deposits, despite some of the differences in their geochemistry. At least a partial continuum of the two end-member porphyry types could be expected (e.g., Zhu et al., 2010; Taylor et al., 2012), and such would accommodate the Kivilompolo mineralization.

The deformation history and geochrononology of the Kierovaara suite and the coeval Hosiojoki suite at the margins of the Peräpohja belt attest that the magmatism was pre-orogenic, as the Svecofennian orogeny began tens of millions of years later, at ca. 1.92 Ga (Lahtinen et al., 2015, and references therein). The tectonic setting of these felsic suites was not subduction related but they represent continental rift-related melts. The Kierovaara granites yield negative initial $\varepsilon_{\mathrm{Nd}}$ values of -4 (Ranta et al., 2015; Lahtinen et al., 2019) indicating they have a significant Archean crustal component in their source (Ranta et al., 2015; Lahtinen et al., 2019). In contrast, the Hosiojoki suite felsic rocks show an A-type chemical affinity and are interpreted as melts from a different crustal source (Lahtinen et al., 2019). Lahtinen et al. (2019) proposed that the Kierovaara granites were derived from a source in the hydrous lower Archean crust, as a result of mafic magmatic underplating, whereas the A-type granites could represent partial melts of a dry mafic underplate. The flat HREE patterns of the Kivilompolo granites indicate that the melting episode left a garnet-free residue, generating a granitic melt relatively undepleted in HREE. This implies that the parental magma of the Kierovaara-type granites was a product of relatively low-pressure melting, below garnet stability $(<10$ kbar; Moyen \& Stevens, 2006). 


\subsection{Molybdenite Re-Os age and its implications}

The obtained molybdenite Re-Os age is similar to the U-Pb zircon age for the hosting Kierovaara granite (ca. 2.0 Ga; Ranta et al., 2015; Lahtinen et al., 2019) implying that the Mo mineralization was formed during the cooling of the magmatic body, probably due to the magma becoming saturated in a magmatic fluid phase. In magmatic-hydrothermal systems, the behavior and enrichment of $\mathrm{Cu}$ and $\mathrm{Mo}$ into magmatic fluid during cooling of the magmatic body is dependent on the timing of fluid saturation and the initial water content of the magma (e.g., Robb, 2005). Cu behaves as a compatible element before the fluid saturation of the magma (Taylor et al., 2012 and references therein). After the fluid saturation is attained, $\mathrm{Cu}$ act as an incompatible element during the crystallization process. In contrast, Mo behaves as incompatible element throughout the crystallization. It is generally thought that in shallow crustal settings, magmas that reach fluid saturation relatively early will have high $\mathrm{Cu} / \mathrm{Mo}$ ratios since $\mathrm{Cu}$ has not yet been incorporated into crystallizing phases. In these settings, due to the low fractionation of the magmas at the time of the fluid saturation, initial Mo content of the magma is relatively low (e.g., Robb, 2005, and references therein), and therefore, the amount of the Mo entering into the fluid is not enough to produce Mo- $(\mathrm{Cu})$ porphyry deposits. In contrast, magmas that attain fluid saturation in a more advanced stage of fractional crystallization (e.g., due to a lower initial water content) will generally have a higher $\mathrm{Mo} / \mathrm{Cu}$ ratio because of a more incompatible nature of Mo into the crystallizing phases compared to $\mathrm{Cu}$. Therefore, at this stage, a large proportion of $\mathrm{Cu}$ had already been lost into the crystallizing minerals during cooling, hence increasing the $\mathrm{Mo} / \mathrm{Cu}$ ratio of the evolving fluid phase. At Kivilompolo, no significant $\mathrm{Cu}$ has been reported. This suggests that fluid saturation was obtained relatively late in the cooling stage.

In Figure 9, geochronological data from the northern part of the Peräpohja belt, including the
Rompas-Rajapalot Au-Co occurrences located approximately $30 \mathrm{~km}$ NE of Kivilompolo, are compared with the data from the Kivilompolo molybdenite. According to Molnár et al. (2017), the $\mathrm{Pb}-\mathrm{Pb}$ ages of uraninite and the Re-Os ages of molybdenite grains in the Rompas Au occurrence are both ca. 2.0-2.05 Ga and represent the age of the primary uranium mineralization. These Rompas-Rajapalot ages are similar to the Kivilompolo Re-Os molybdenite ages. Molnár et al. (2017) proposed that the potential source for U-bearing hydrothermal fluids is basinal fluids circulating during late-stage basin evolution. Furthermore, Cook et al. (2019) reported a monazite U-Pb age for albitized granodiorite from the Rajapalot area, located approximately $8 \mathrm{~km}$ east of Rompas (Fig. 2). The oldest monazite yields an age of 2016 $\pm 17 \mathrm{Ma}$, which is consistent, within error, with the Kivilompolo molybdenite Re-Os ages (Fig. 9).

Magmatic-hydrothermal fluid circulation in and around magmatic intrusions (especially in porphyry deposits) may have a far-reaching footprint. In alkali-feldspar rhyolite-granite-related porphyry Mo systems, elevated fluorine and uranium may be detected kilometers, even tens of kilometers away from large porphyry bodies (Ludington \& Plumlee, 2009). The heat provided by intruding magmas can potentially initiate circulation of basinal fluids. In the Peräpohja belt and other similar Precambrian intracratonic successions in the Fennoscandian Shield, the former presence of evaporite rocks has been indicated in several studies (e.g., Kyläskoski et al., 2012; Ranta et al., 2017; Vasilopoulos et al., 2019). In the Peräpohja belt, an anhydrite-bearing rock interval was encountered during drilling in the Rajapalot area (Cook et al., 2019). Evaporite beds in the stratigraphy provide sources for highly saline fluids, capable of oxidizing and mobilizing a wide range of metals (including $\mathrm{Mo}, \mathrm{Cu}$ and $\mathrm{U}$ ) from the surrounding rocks. The potential contribution of magmatic fluids to the fluid and metal budget in the Rompas-Rajapalot area cannot be fully evaluated at this stage. Nevertheless, the obtained geochronological data are consistent 


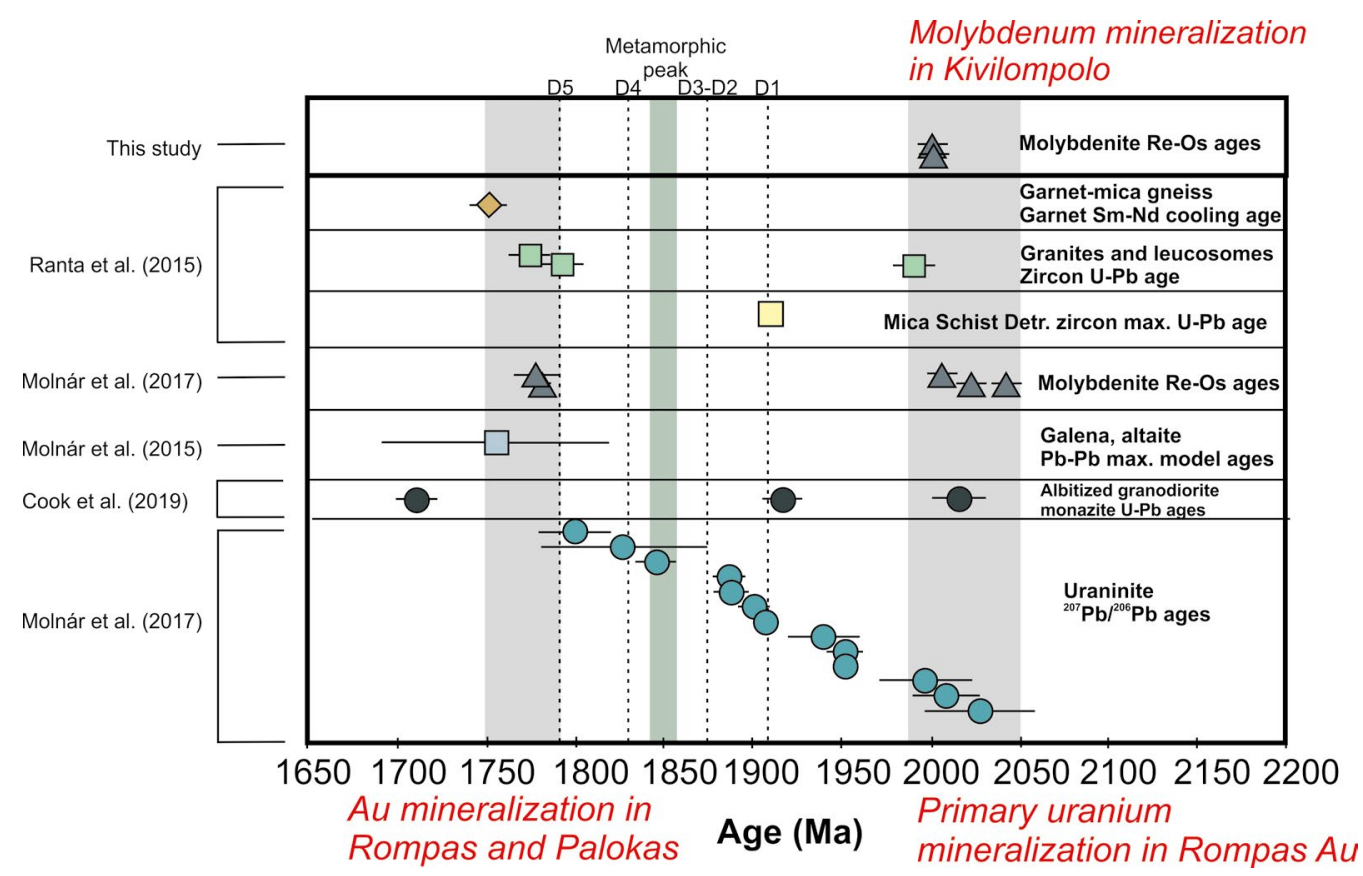

Figure 9. Comparison of different dating results from metal occurrences in the northern part of the Peräpohja belt (modified after Molnár et al., 2017, and Cook et al., 2019). Note that the Re-Os age of molybdenite from Kivilompolo is similar to the Re-Os age of molybdenite, the oldest ${ }^{207} \mathrm{~Pb}-{ }^{206} \mathrm{~Pb}$ age of uraninite and the oldest $\mathrm{U}-\mathrm{Pb}$ age of monazite from the Rajapalot-Rompas Au-Co-(U) occurrence. Svecofennian metamorphic evolution after Lahtinen et al. (2015). Deformation stages (D1-D5) of svecofennian tectonic evolution are indicated as dashed lines.

with the hypothesis that the magmatic event producing the Kierovaara and Hosiojoki suite rocks was at minimum a heat engine, and may have also provided fluids for a more regional magmatic-hydrothermal system responsible for the precipitation of metals throughout the northern part of the Peräpohja belt. Although the currently available data from Kivilompolo indicate that the extent and grade of the Mo occurrence are limited, our study provides valuable information on the greater mineralizing processes in the Peräpohja belt.

\section{Conclusions}

Based on our Re-Os dating of molybdenite and whole-rock geochemical data, we draw the following conclusions:

1) The major and trace element compositions of the unnamed granite hosting the Kivilom- polo Mo occurrence closely match those of the Kierovaara granite suite.

2) The $2001 \pm 8$ and $2003 \pm 7 \mathrm{Ma}$ Re-Os ages for molybdenite from the Kivilompolo Mo occurrence are similar to the U-Pb zircon age of ca. 2.0 Ga published for Kierovaara suite.

3) The Kivilompolo Mo occurrence resembles porphyry-type Mo deposits but does not have any distinctive features that could be used to classify it into any subtype of porphyry deposits.

4) Based on the geochronological data, the ca. 2.0 Ga mineralizing event at Kivilompolo may be genetically related to processes that formed primary uranium (and cobalt)mineralization in the Rompas-Rajapalot $\mathrm{Au}-\mathrm{Co}$ occurrence in the northern part of the Peräpohja belt. 
5) The emplacement of the Kierovaara granitic suite is a potential heat source for triggering the circulation of early saline basinal fluids carrying metals in the Peräpohja belt. These granites could also have provided the fluids and metals for a large magmatic-hydrothermal system that includes the initial metal enrichment at the Rompas-Rajapalot Au-Co occurrence.

\section{Acknowledgements}

We thank Pyhäsalmi Mine Oy for providing drill core geochemical data from the Kivilompolo area.

\section{References}

Barton, M.D. \& Young, S., 2002. Non-pegmatitic deposits of beryllium: Mineralogy, geology, phase equilibrium and origin. In: Grew, E.S. (eds.), Beryllium: Mineralogy, Petrology and Geochemistry, Reviews in Mineralogy and Geochemistry, vol. 50, pp. 591-691.

https://doi.org/10.2138/rmg.2002.50.14

Bingen, B. and Stein, H., 2003. Molybdenite Re-Os dating of biotite dehydration melting in the Rogaland hightemperature granulites, S Norway. Earth and Planetary Science Letters 208, 181-195. https://doi.org/10.1016/S0012-821X(03)00036-0

Cook, N., Molnár, F., O` Brien, H., Lahaye, Y. \& Tapio, J. 2019. The evolution of the Peräpohja belt as viewed from within the Rompas-Rajapalot project. NEXT $-3^{\text {rd }}$ Progress Meeting 7-10 October, 2019, Pohtilampi, Rovaniemi, Finland, Abstracts with Programs, pp. 13-16.

DePaolo, D.J., 1981. Trace element and isotopic effects of combined wall-rock assimilation and fractional crystallization. Earth and Planetary Science Letters 53, 189-202. https://doi.org/10.1016/0012-821X(81)90153-9

Frost, B.R., Barnes, C.G., Collins, W.J., Arculus, D.J.E. \& Frost, C.R., 2001. A geochemical classification for granitic rocks. Journal of Petrology 42, 2033-2048. https://doi.org/10.1093/petrology/42.11.2033

Goode, M., 2019. Mineralogy and geochemistry of the Kivilompolo molybdenum mineralization in the Peräpohja belt, northern Finland. M.Sc. Thesis, University of Oulu, Finland, $57 \mathrm{p}$.

Haapala, I. \& Rämö, O.T., 2015. Mineral deposits related to granitic rocks. In: Maier, W.D., O’Brien, H., Lahtinen, R. (eds.), Mineral Deposits of Finland. Elsevier, Amsterdam, pp. 531-551.

https://doi.org/10.1016/b978-0-12-410438-9.00018-2
Colorado State University provides no salaries or operational support for the AIRIE Program. We thank AIRIE lab manager Aaron Zimmerman for his help. Kimmo Kärenlampi is thanked for helping in the geochemical sample preparation. We thank Tapani Rämö and Kirill I. Lokhov for their useful comments and suggestions that significantly improved this paper.

\section{Supplementary data}

Electronic Appendix A for this article is available via Bulletin of the Geological Society of Finland web page.

Haapala, I., Front, K., Rantala, E. \& Vaarma, M., 1987. Petrology of Nattanen-type granite complexes, northern Finland. Precambrian Research 35, 225-240. https://doi.org/10.1016/0301-9268(87)90056-8

Hanski, E., Huhma, H. \& Vuollo, J., 2010. SIMS zircon ages and $\mathrm{Nd}$ isotope systematics of the $2.2 \mathrm{Ga}$ mafic intrusions in northern and eastern Finland. Bulletin of the Geological Survey of Finland 82,31-62. https://doi.org/10.17741/bgsf/82.1.002

Heilimo, E., Halla, J., Lauri, L.S., Rämö, O. T., Huhma, H., Kurhila, M., \& Front, K., 2009. The Paleoproterozoic Nattanen-type granites in northern Finland and vicinity - a postcollisional oxidized A-suite. Bulletin of the Geological Society of Finland 81,7-38 Part I. https://doi.org/10.17741/bgsf/81.1.001

Huhma, H., Cliff, R.A., Perttunen, V. \& Sakko, M., 1990. Sm$\mathrm{Nd}$ and $\mathrm{Pb}$ isotopic study of mafic rocks associated with early Proterozoic continental rifting: the Peräpohja schist belt in northern Finland. Contribution to Mineralogy and Petrology 104, 369-379. https://doi.org/10.1007/BF00321491

Huhma, H., Hanski, E., Kontinen, A., Vuollo, J., Mänttäri, I. \& Lahaye, Y., 2018. Sm-Nd and U-Pb isotope geochemistry of the Palaeoproterozoic mafic magmatism in eastern and northern Finland. Geological Survey of Finland, Bulletin 405, 150.

Iljina, M. \& Hanski, E., 2005. Layered mafic intrusions of the Tornio-Näränkävaara belt. In: Lehtinen, M., Nurmi, P.A., Rämö, O.T. (eds.), Precambrian Geology of Finland - Key to the Evolution of the Fennoscandian Shield. Elsevier B.V, Amsterdam, pp. 101-138. https://doi.org/10.1016/S0166-2635(05)80004-0 
John, D.A. \& Taylor, R.D., 2016. Byproducts of porphyry copper and molybdenum deposits. In: Vernplanck, P.L., Hitzman, M.W. (eds.), Rare-earth and critical elements in ore deposits. Reviews in Economic Geology, 18, 137-164. https://doi.org/10.5382/REV.18

Kärenlampi, K., Kontinen, A., Huhma, H. \& Hanski, E., 2019. Geology, geochronology and geochemistry of the $2.05 \mathrm{Ga}$ gneissic A1-type granites and related intermediate rocks in central Finland: implication for the tectonic evolution of the Karelia craton margin. Bulletin of the Geological Society of Finland 91,35-73.

https://doi.org/10.17741/bgsf/91.1.002

Karhu, J., Kortelainen, N.M., Huhma, H., Perttunen, V. \& Sergeev, S. 2007. New time constraints for the end of the Paleoproterozoic carbon isotope excursion. In $7^{\text {th }}$ International Symposium on Applied Isotope Geochemistry, 10th-14th Sept., 2007, Stellenbosch, S Africa, pp. 76-77.

Kyläkoski, M., Hanski, E. \& Huhma, H., 2012. The Petäjäskoski Formation, a new lithostratigraphic unit in the Paleoproterozoic Peräpohja Belt, northern Finland. Bulletin of the Geological Society of Finland 84, 85-120. https://doi.org/10.17741/bgsf/84.2.001

Köykkä, J., Lahtinen, R. \& Huhma, H., 2019. Provenance evolution of the Paleoproterozoic metasedimentary cover sequences in northern Fennoscandia: Age distribution, geochemistry, and zircon morphology. Precambrian Research 331, 105364. https://doi.org/10.1016/j.precamres.2019.105364

Lahtinen, R., Mohammad, S. \& Fredrik, K., 2015. Nearorthogonal deformation successions in the polydeformed Proterozoic Martimo belt: Implications for the tectonic evolution of Northern Fennoscandia. Precambrian Research 270, 22-38.

https://doi.org/10.1016/j.precamres.2015.09.003

Lahtinen, H., Huhma, H., Laura, L.S. \& Sayab, M., 2019. Geochemical and $\mathrm{U}-\mathrm{Pb}$ and $\mathrm{Sm}-\mathrm{Nd}$ isotopic constraints on the evolution of the Paleoproterozoic Ylitornio nappe complex, northern Fennoscandia. Bulletin of the Geological Society of Finland 91,75-100.

https://doi.org/10.17741/bgsf/91.1.003

Lawley, C.J.M., Richards, J.P., Anderson, R.G., Creaser, R.A. \& Heaman, L.M., 2010. Geochronology and geochemistry of the MAX porphyry Mo deposit and its relationship to $\mathrm{Pb}-\mathrm{Zn}-\mathrm{Ag}$ mineralization, Kootenay arc, southeastern British Columbia, Canada. Economic Geology 105, 1113-1142.

https://doi.org/10.2113/econgeo.105.6.1113

Ludington, S. \& Plumlee, G.S., 2009. Climax-type porphyry molybdenum deposits. Geological Survey Open-File Report 2009-1215, $16 \mathrm{p}$.

Ludington, S., Hammarstrom, J. \& Piatak, N., 2009. Lowfluorine stockwork molybdenite deposits. U.S. Geological Survey Open-File Report 2009-1211,9 p.
Markey, R.J., Stein, H.J., Morgan, J.W. \& Hannah, J.L., 1999. Comparison of alkaline fusion versus Carius tube digestion for Re-Os dating of molybdenite: lessons from the Aittojärvi, Finland standard. Geological Society of America, Abstracts with Programs, 31/7, A-95.

Markey, R.J., Hannah, J.L., Morgan, J.W. \& Stein, H.J., 2003. A double spike for osmium analysis of highly radiogenic samples. Chemical Geology 200,395-406. https://doi.org/10.1016/S0009-2541(03)00197-9

Molnár, F., Oduro, H., Cook, N.D.J., Pohjolainen, E., Takacs, A., O’Brien, H., Pakkanen, L., Johanson, B. \& Wirth, R., 2016. Association of gold with uraninite and pyrobitumen in the metavolcanic rock hosted hydrothermal $\mathrm{Au}-\mathrm{U}$ mineralization at Rompas, Peräpohja Schist Belt, northern Finland. Mineralium Deposita 51, 681-702. https://doi.org/10.1007/s00126-015-0636-6

Molnár, F., O`Brien, H., Stein, H. \& Cook, N., 2017. Geochronology of hydrothermal processes leading to the formation of the $\mathrm{Au}-\mathrm{U}$ mineralization at the Rompas prospect, Peräpohja belt, Northern Finland: Application of paired U-Pb dating of uraninite and $\mathrm{Re}-\mathrm{O} s$ dating of molybdenite to the identification of multiple hydrothermal events in a metamorphic terrane. Minerals 7, 171. https://doi.org/10.3390/min7090171

Molnár, F., Middelton, A., Stein, H., O’Brien, H., Lahaye, Y., Huhma, H., Pakkanen, L. \& Johanson, B., 2018. Repeated syn- and post-orogenic gold mineralization events between 1.92 and 1.76 Ga along Kiistala Shear Zone in the Central Lapland greenstone belt, northern Finland. Ore Geology Reviews 101, 936-959. https://doi.org/10.1016/j.oregeorev.2018.08.015

Moyen, J-F. \& Stevens, G., 2006. Experimental constraints on TTG petrogenesis: Implication for Archean Geodynamics. Archean Geodynamics and Environments, Geophysical Monograph Series 164, 149-175. https://doi.org/10.1029/164GM11

Nironen, M., 2017. Structural interpretation of the Peräpohja and Kuusamo belts and Central Lapland, and a tectonic model for northern Finland. Geological Survey of Finland, Report of Investigation 234, $53 \mathrm{p}$.

Nurmi, P.A. \& Sorjonen-Ward, P., 1993, Geological Development, Gold Mineralization and Exploration Methods in the Late Archean Hattu Schist Belt, Ilomantsi, Eastern Finland. Geological Survey of Finland, Special Paper 17, $386 \mathrm{p}$.

Pearce, J.A., 1983. Role of the sub-continental lithosphere in magma genesis at active continental margins. In: Hawkesworth, C.J., Norry, M.J. (eds.), Continental Basalts and Mantle Xenoliths, Shiva Publishing Ltd., Cambridge, Mass., pp. 230-249.

Perttunen, V. \& Vaasjoki, M., 2001. U-Pb geochronology of the Peräpohja Schist Belt, northwestern Finland. Geological Survey of Finland, Special Paper 33, 45-84. 
Perttunen, V., Hanski, E. \& Väänänen, J., 1995. Stratigraphical map of the Peräpohja Schist Belt. In: 22 $2^{\text {nd }}$ Nordic Geological Winter Meeting, January 8-11, 1996, Turku, Abstracts, p. 152.

Piippo, S., Skyttä, P. \& Kloppenburg, A., 2019. Linkage of crustal deformation between the Archean basement and the Proterozoic cover in the Peräpohja area, northern Fennoscandia. Precambrian Research 324, 285-302. https://doi.org/10.1016/j.precamres.2019.02.003

Ranta, J-P., Lauri, L.S., Hanski, E., Huhma, H., Lahaye, Y. \& Vanhanen, E., 2015. U-Pb and Sm-Nd isotopic constraints on the evolution of the Paleoproterozoic Peräpohja Belt, northern Finland. Precambrian Research 266, 246-259.

https://doi.org/10.1016/j.precamres.2015.05.018

Ranta, J.-P., Hanski, E., Cook, N. \& Lahaye, Y., 2017. Source of boron in the Palokas gold deposit, northern Finland: Evidence from boron isotopes and major element composition of tourmaline. Mineralium Deposita 52, 733-746. https://doi.org/10.1007/s00126-016-0700-x

Ranta, J.-P., Molnár, F., Hanski, E. \& Cook, N., 2018. Epigenetic gold occurrence in a Paleoproterozoic meta-evaporitic sequence in the Rompas-Rajapalot $\mathrm{Au}$ system, Peräpohja belt, northern Finland. Bulletin of the Geological Society of Finland 90, 69-108. https://doi.org/10.17741/bgsf/90.1.004

Richards, J.P., 2011. High Sr/Y arc magmas and porphyry $\mathrm{Cu} \pm \mathrm{Mo} \pm \mathrm{Au}$ deposits: Just add water. Economic Geology 106, 1075-1081. https://doi.org/10.2113/econgeo.106.7.1075

Robb, L., 2005. Introduction to Ore-forming Processes. Blackwell Publishing, United Kingdom, 386 p.

Selby, D. \& Creaser, R.A., 2004. Macroscale NTIMS and microscale La-Mc-ICP-MS Re-Os isotopic analysis of molybdenite: Testing spatial restrictions for reliable Re-Os age determinations, and implications for the decoupling of $\mathrm{Re}$ and Os within molybdenite. Geochimica et Cosmochimica Acta 68, 3897-3908. https://doi.org/10.1016/j.gca.2004.03.022

Sillitoe, R.H., 2010. Porphyry copper systems. Economic Geology 105,3-41. https://doi.org/10.2113/gsecongeo.105.1.3

Sinclair, W.D., 2007. Porphyry deposits. In: Goodfellow, W.D. (eds.), Mineral Deposits of Canada: A Synthesis of Major Deposits Types, District Metallogeny, the Evolution of Geological Provinces, and Exploration Methods. Geological Association of Canada, Minerals Deposit Division, Special Publication 5, pp. 223-243.

Stein, H.J., 1988. Genetic traits of Climax-type granites and molybdenum mineralization, Colorado Mineral Belt. In: Taylor, R.P., Strong, D.F. (eds.), Recent Advances in the Geology of Granite-Related Mineral Deposits. Canadian Institute of Mining and Metallurgy, Special Volume 39, 394-401.
Stein, H.J., 2006. Low-rhenium molybdenite by metamorphism in northern Sweden: recognition, genesis, and global implications. Lithos 87, 300-327. https://doi.org/10.1016/j.lithos.2005.06.014

Stein, H.J., 2014. Dating and tracing the history of ore formation. In: Holland, H.D., Turekian, K.K. (eds.), Treatise on Geochemistry, Second edition, Vol. 13, pp. 87-118.

Stein, H.J., Sundblad, K., Markey, R.J., Morgan, J.W. \& Kouvo, O., 1995. New method for precise Re-Os dating reveals two generations of molybdenite at Mätäsvaara, Karelian Province of eastern Finland: in Glebovitsky, V.A., Kotov, A.B. (eds.), Precambrian of Europe: Stratigraphy, Structure, Evolution and Mineralization (MAEGS- 9), Abstract Volume, Russian Academy of Sciences and Institute of Precambrian Geology and Geochronology, St. Petersburg, Russian Federation, pp. 112-113.

Stein, H.J., Markey, R.J., Morgan, J.W., Du, A. \& Sun, Y., 1997. Highly precise and accurate Re-Os ages for molybdenite from the East Qinling molybdenum belt, Shaanxi Province, China. Economic Geology 92, $827-835$.

https://doi.org/10.2113/gsecongeo.92.7-8.827

Stein, H.J., Sundblad, K., Markey, R.J., Morgan, J.W. \& Motuza, G., 1998. Re-Os ages for Archean molybdenite and pyrite, Kuittila- Kivisuo, Finland and Proterozoic molybdenite, Kabeliai, Lithuania: testing the chronometer in metamorphic and metasomatic setting. Mineralium Deposita 33, 329-345. https://doi.org/10.1007/s001260050153

Stein, H.J., Markey, R.J., Morgan, J.W., Hannah, J.L. \& Scherstén, A., 2001. The remarkable Re-Os chronometer in molybdenite: how and why it works. Terra Nova 13, 479-486. https://doi.org/10.1046/j.1365-3121.2001.00395.x

Stein, H., Scherstén, A., Hannah, J. \& Markey, R., 2003. Subgrain scale decoupling of Re and ${ }^{187} \mathrm{Os}$ and assessment of laser ablation ICP-MS spot dating in molybdenite. Geochimica et Cosmochimica Acta 67, 3673-3686. https://doi.org/10.1016/S0016-7037(03)00269-2

Streckeisen, A. \& Le Maitre, R.W.L., 1979. A chemical approximation to modal QAPF classification of the igneous rocks. Neues Jahrbuch fur Mineralogie Abhandlungen 136, 169-206.

Sun, S.-S. \& McDonough, W.F., 1989. Chemical and isotopic systematics of oceanic basalts; implications for mantle composition and processes. In: Saunders, A.D., Norry, M.J. (eds.) Magmatism in the Ocean Basins. Geological Society of London, Special Publication 42, 313-345. https://doi.org/10.1144/GSL.SP.1989.042.01.19

Tainio, J., 2014. Rovaniemen kunnassa sijaitsevien Vanttauksen, Lehmikarin ja Äijävaaran appiniitti-intruusioiden petrografian ja geokemian tutkimus. M.Sc. Thesis, Department of Geosciences and Geography, University of Helsinki, 93 p. 
Taylor, R.D., Hammarstrom, J.M., Piatak, N.M. \& Seal, R.R.II., 2012. Arc-related porphyry molybdenum deposit model, chapter D of Mineral deposit models for resource assessment. U.S. Geological Survey, Scientific Investigations Report 2010-5070-D, 64 p. https://doi.org/10.3133/sir20105070D

Vanhanen, E., 2001. Geology, mineralogy and geochemistry of the $\mathrm{Fe}-\mathrm{Co}-\mathrm{Au}-(\mathrm{U})$ deposits in the Paleoproterozoic Kuusamo Schists Belt, northeastern Finland. Geological Survey of Finland, Bulletin 399, 229 p.

Vanhanen, E., Cook, N.D.J., Hudson, M.R., Dahlenborg, L., Ranta, J-P., Havela, T., Kinnunen, J., Molnár, F., Prave, A.R. \& Oliver, N.H.S., 2015. The Rompas prospect, Peräpohja schist belt, northern Finland. In: Maier, W.D., O'Brien, H, Lahtinen, R (eds.), Mineral Deposits of Finland. Elsevier, Amsterdam, pp. 467-484. https://doi.org/10.1016/b978-0-12-410438-9.00018-2

Vasilopoulos, M., Ranta, J-P., Molnár, F., O`Brien, H. \& Lahaye, Y., 2019. Sulphide trace element, sulphur isotope and hydrothermal alteration studies in the Juomasuo and Hangaslampi Au-Co deposits, Kuusamo belt., northeastern Finland. Proceeding of the 15th Biennial SGA meeting, 27-30 August 2019, Glasgow, Scotland, pp. 193-196.
Wyche, N.L., Eilu, P., Koppström, K., Kortelainen, V.J., Niiranen, T. \& Välimaa, J., 2015. The Suurikuusikko gold deposit (Kittilä mine), northern Finland. In: Maier, W.D., O’Brien, H., Lahtinen, R. (eds.), Mineral Deposits of Finland. Elsevier, Amsterdam, pp. 411-430. https:/doi.org/10.1016/b978-0-12-410438-9.00018-2

Yletyinen V., 1967. On the molybdenite occurrence at Kivilompolo, Ylitornio. Geological Survey of Finland, Geotechnical Publications 73, 24 p. (In Finnish with English summary)

Zhang, H., Li, C-Y., Yang, X-Y., Sun, Y-L., Deng, J-H., Liang, H-Y., Wang, R-L., Wang, B-H., Wang, Y-X. \& Sun, W-D., 2014. Shapinggou: the largest Climax-type porphyry Mo deposit in China. International Geology Reviews 56, 313-331. https://doi.org/10.1080/00206814.2013.855363

Zhu, L., Zhang, G., Guo, B., Lee, B., Gong, H. \& Wang, F., 2010. Geochemistry of the Jinduicheng MoBearing porphyry and deposit, and its implication for the geodynamic setting in East Qinling, P.R. China. Geochemistry 70, 259-174.

https://doi.org/10.1016/j.chemer.2009.12.003 